\title{
微生物核酸簡易抽出キットの比較検討
}

黒崎陽平 1 , 堀内秀紀 ${ }^{2}$, 橋本幸二 ${ }^{2}$, 吉野峰生 ${ }^{1}$, 安田二朗 1

\author{
1科学警察研究所 \\ 干277-0882 千葉県柏市柏の葉 6-3-1 \\ 2株式会社東芝 \\ 干105-8001 東京都港区芝浦 1-1-1
}

\section{Comparative Study of Commercial Nucleic Acid Extraction Kits for Detecting Microorganism}

\author{
Yohei Kurosaki $^{1}$, Hideki Horiuchi ${ }^{2}$, Koji Hashimoto ${ }^{2}$, Mineo Yoshino $^{1}$ and Jiro Yasuda ${ }^{1}$ \\ ${ }^{1}$ National Research Institute of Police Science, \\ 6-3-1 Kashiwanoha, Kashiwa, Chiba 277-0882, Japan \\ ${ }^{2}$ Toshiba Corporation, 1-1, Shibaura 1-Chome, Minato-ku, Tokyo 105-8001, Japan
}

(Received 5 January 2012; accepted 30 July 2012)

Isolation of high-quality nucleic acids of microorganism is essential for the molecular testing of biological warfare agents (BAs). In this study, we evaluated three commercially available nucleic acid extraction kits, IT1-2-3 ${ }^{\mathrm{TM}}$ (IT), Bio Bulwark $^{\mathrm{TM}}$ pretreatment reagent kit (BB) and MORA EXTRACT (ME), using spores of Bacillus subtilis as a model of Bacillus anthracis. The extraction efficiencies of genomic DNA using IT and BB were approximately $10 \%$ and $30 \%$, respectively. The ratio of absorbance $(260 \mathrm{~nm} / 280 \mathrm{~nm})$ of each extracted sample showed from 1.7 to 2.0 , and indicated that the purity of extracted DNA using these kits was sufficient for the molecular testing. BB could inactivate more than $5 \times 10^{7}$ spores at the beads beating process. While surviving spores were detected after the beads beating process of IT, and the residual spores might be captured in a spin column filter. Although these kits are enabled for the extraction of nucleic acids of BAs with easy handling, the efficiency of extraction and efficacy of inactivation of BAs are different. So it is important to understand the characteristics of each kit before use.

Key words: Biological warfare agent, Nucleic acid extraction, Genomic DNA, Bacillus subtilis, Spore

\section{緒 言 \\ 2001年の米国における「炭疽菌郵送事件」の発生}

以降，バイオテロへの危惧が高まるとともに，バイ オテロ発生に備えた対応の整備が社会的に求められ ている.バイオテロの発生が疑われた場合，使用さ 
れた生物剤の迅速な検知および同定が初動の方向性 を決定する上で最も重要である1)。現在，生物剤の 迅速な現場検知を行うため，免疫学的手法や分子生 物学的手法を測定原理とするシステムが実用化され ているが1)，検出感度や精度の観点から後者がより 優れており，有用性が高い。

分子生物学的手法は，生物剂に分類される微生物 の有無を遺伝子レベルで調べるもので，(1)被疑試料 から微生物の遺伝子を含む核酸成分を抽出/精製,

(2)核酸成分に含まれる微生物の遺伝子を酵素反応を 使って増幅，(3)増幅した遺伝子の配列を解析し生物 凨の有無を判定，の3つの工程から構成されてい る. 生物剤を精確かつ高感度に検出するためには, 高品位の核酸（遺伝子）を効率良く抽出/精製する ことが必要であり，また検査中は作業者が被疑試料 に含まれる生物剤に曝露される危険性があるため, 核酸抽出/精製工程の初期段階で微生物を高度に不 活化することも重要である.

本研究では, 生物剤検知システムで使用されてい る核酸抽出試薬々一般的な研究用核酸抽出キット中 で芽胞から核酸抽出が可能な核酸抽出試薬につい
て, 抽出した核酸の収量や純度, 抽出に対する不純 物の影響，更には微生物の不活化能の評価を行った ので報告する.

\section{材料および方法}

\section{1. 材料}

核酸抽出キットの比較検討には，枯草菌芽胞（枯 草菌6633, 栄研化学) を用いた。芽胞懸濁液は氷上 保存とし，位相差顕微鏡観察にて光屈折性を示す芽 胞が一視野当たり 99\%以上であること確認の上，実 験に用いた。枯草菌のゲノムDNAは，ATCC (American Type Culture Collection) より購入した 枯草菌 ATCC6633 株のゲノム DNA を使用した。

\section{2. 枯草菌の検出および定量}

枯草菌芽胞の検出は希釈平板法で行った．水冷し た滅菌生理食塩水で段階希釈した試料 $100 \mu \mathrm{L}$ を LB 寒天培地に塗沫後, $37^{\circ} \mathrm{C}$ で一晚培養し, プレート上 に形成したコロニー数から枯草菌芽胞数（colony forming unit: cfu）を算出した.

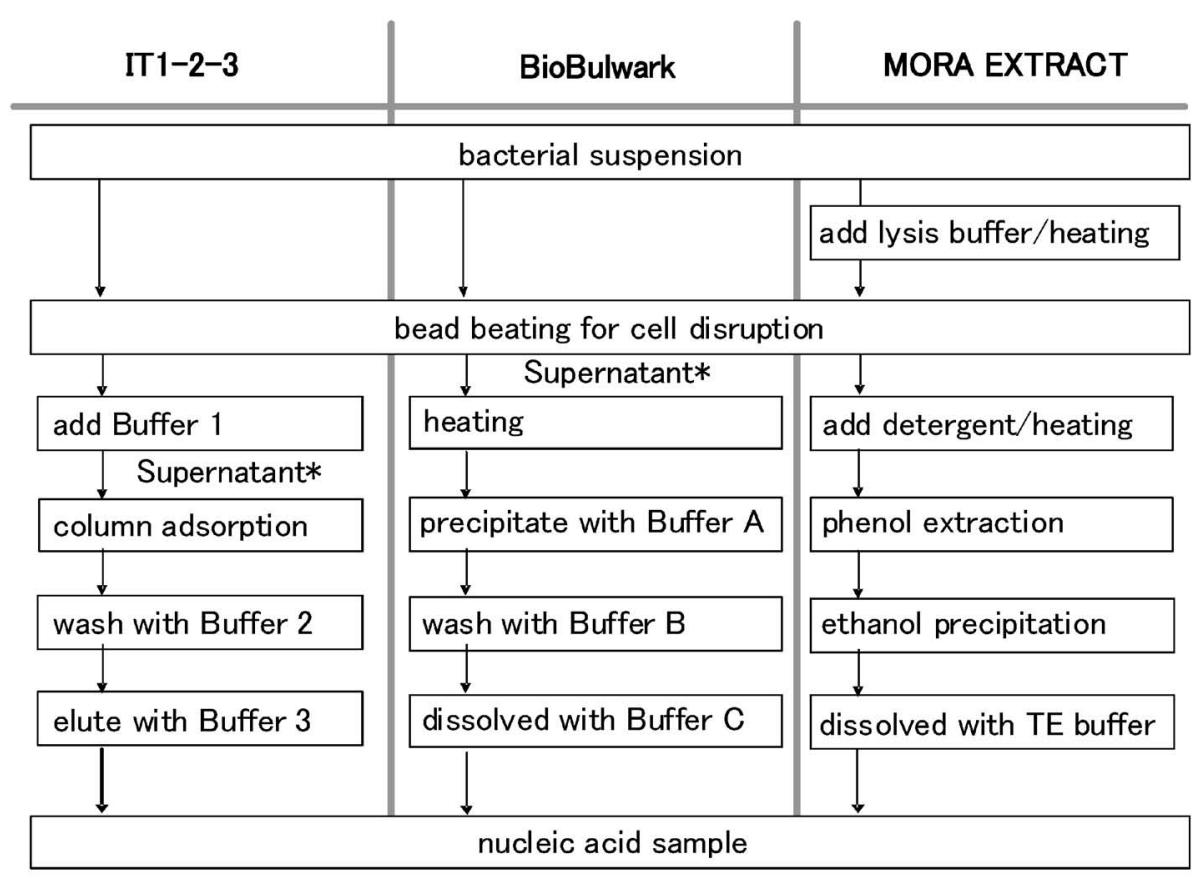

* Used for viability test in Fig.4

Fig. 1 Schematic representation of the nucleic acid extraction processes used in this study. The supernatants after beads beating $\left(^{*}\right)$ were used for detection of viable cells. 


\section{3. 核酸抽出物の評価}

核酸抽出キットには, 生物剂検知システム R.A.P.I.D. ${ }^{\mathrm{TM}}$ (Idaho Technology) で使用されてい る生物剤検出用核酸抽出試薬 IT1-2-3 ${ }^{\mathrm{TM}}$ Sample Purification kits (Idaho Technology, 以下 IT と略 記), BioBulwark ${ }^{\mathrm{TM}}$ (東芝) に付属する前処理試薬 キット（東芝，以下 BB と略記）および研究用核酸 抽出試薬 MORA EXTRACT（極東製薬，以下 ME と略記）を用いた2)。核酸抽出は，各製品添付の取 扱説明書に従い実施した (Fig. 1). 各抽出法に用 いる芽胞量は $5 \times 10^{8} \mathrm{cfu}$ とし，上記芽胞懸濁液を精 製水で適宜希釈の上，各反応チューブに添加した.

核酸の濃度は分光光度計（DU-800; Beckman Coulter）を用いて $260 \mathrm{~nm}$ の吸光度から算出した。 核酸抽出液の精製度は，260 nm と280 nm の吸光度 の比から算出した。核酸抽出液中の枯草菌ゲノム DNA は，リアルタイム PCR 装置（Mx3005 $\mathrm{P}^{\circledR}$ QPCR System；Agilent）を用いて定量した。リア

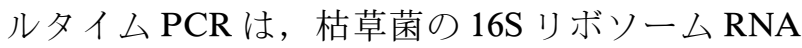
遺伝子を増幅ターゲットとしたプライマー（5'GGGAGCGAACAGGATT - 3 ', 5 'CATGCTCCACCGCTTGTG-3'）々増幅用試薬 Brilliant $^{\mathrm{TM}}$ Fast SYBR Green QPCR Master Mix (Agilent) を用いて行った（増幅条件: $95^{\circ} \mathrm{C} / 2$ 分を 1 サイクル, $95^{\circ} \mathrm{C} / 5$ 秒 $-60^{\circ} \mathrm{C} / 20$ 秒を 30 サイクル).

ゲノム DNA 量 (copy 数) は, 枯草菌ゲノム DNA を用いて作成した検量線を基にMxPro QPCR Software (Agilent) で算出した.

抽出した核酸の品質は, アガロースゲル電気泳動 で解析した．抽出液 $10 \mu \mathrm{L}$ を $0.8 \%$ アガロースゲル にて電気泳動し, エチジウムブロマイド染色後, 画 像解析装置（Typhoon；GEヘルスケア）を用いて 解析した.

\section{4. 核酸抽出に対する不純物の影響評価}

不純物としては，塩（天塩），砂糖（日新製糖）, セルロース (Sigma-Aldrich), シリカ (Sigma-Aldrich), スキムミルク (和光純薬), 小麦粉（日清 製粉), クリープ (森永乳業), 味の素 $(\mathrm{L}-$ グルタ ミン酸ナトリウム; 味の素)，パルスイート（アス パルテーム; 味の素), 片栗粉 (十勝士幌農協) を 用いた。不純物の影響評価に用いた 10 種類の物質
は, 米国において実際に炭疽菌芽胞被疑試料として 分析され, 同定された白色粉末の報告例を参考に選 定した ${ }^{3)}$. 枯草菌芽胞 $1 \times 10^{8} \mathrm{cfu}$ に対し不純物を終 濃度 5\%（w/v）になるように調製し, 核酸抽出を 行った。核酸抽出液中に含まれる枯草菌ゲノム DNAをリアルタイムPCR で定量し, 抽出に対す る不純物の影響を評価した。

\section{結 果 \\ 1. 核酸抽出特性の比較}

枯草菌芽胞を用いて, 微生物核酸抽出キット IT，BB，ME の核酸抽出特性を評価した結果， $5 \times$ $10^{8} \mathrm{cfu}$ の枯草菌からは 9 17 $\mu \mathrm{g}$ の核酸成分が抽出 された（Fig. 2A)．枯草菌のゲノムサイズは約 4.2 Mbp であることから ${ }^{4)}$ ，供試した枯草菌から $100 \%$ 抽出できたとすると，ゲノム DNA 量は約 $2 \mu \mathrm{g}$ と なる.よって核酸成分の多くは RNA や低分子の核 酸に由来するものと考えられた。 また，核酸抽出液 の吸光度の比 $(260 \mathrm{~nm} / 280 \mathrm{~nm})$ は $1.7 \sim 2.0$ の範囲 であり， 3 キットともに分子生物学的な解析に用い るサンプルとしては十分な精製度であることが分か った (Fig. 2B). 抽出した核酸成分中の枯草菌ゲノ ム DNA 量をリアルタイム PCR で定量した結果, ITを用いた場合は約 $0.5 \times 10^{8} \pm 0.2 \times 10^{7}$ copies（n $=3 ）$ ， BB を用いた場合は $1.7 \times 10^{8} \pm 1.0 \times 10^{7}$ copies $(\mathrm{n}=3)$ となった。実験に使用した菌体量から計算 すると，ITを用いた場合の抽出効率は約 $10 \%, \mathrm{BB}$ を用いた場合の抽出効率は約 $30 \%$ 程度と算出され た。

次に，抽出した核酸成分の品質と核酸抽出に対す る不純物の影響を BBを用いて評価した。 抽出した 核酸成分をアガロースゲル電気泳動にて解析した結 果, ゲノム DNA と16S，23S リボソーム RNA に由 来するシャープなバンドが確認され5 ${ }^{5)}$ ，いずれも分 解や断片化を示すスメアなバンドは認められなかっ た（Fig. 3)。また，不純物の影響評価では，リア ルタイム PCR の定量值が $2.0 \times 10^{7} \sim 6.3 \times 10^{7}$ copies となり，何も添加しないコントロールと比べ約30～ 95\%であった（Table 1). 小麦粉, 片栗粉で低い值 を示したが，今回検討を行った濃度範囲であれば， 不純物が共存していても芽胞からのゲノムDNAの 


\section{A}

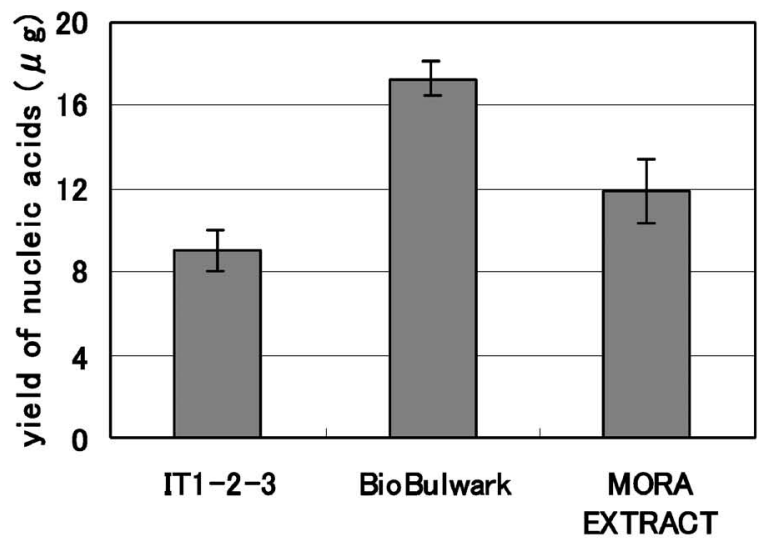

B

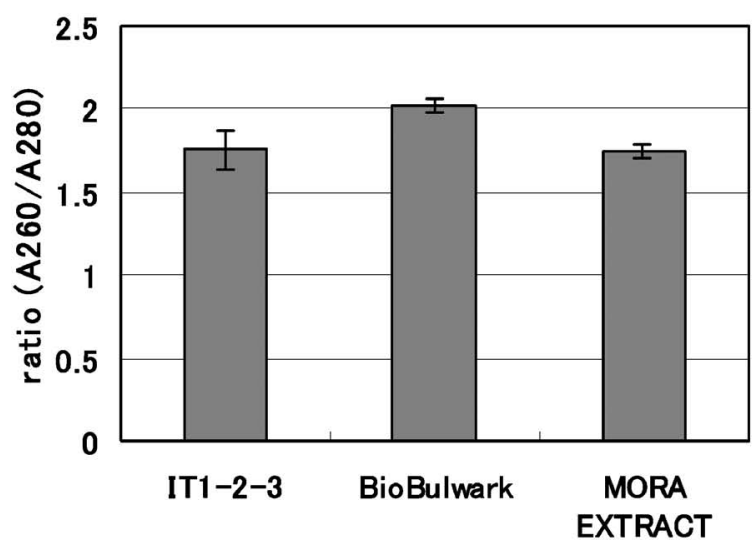

Fig. 2 Spectrometric analysis of bacteria extracts. Yield (A) and purity (B) of nucleic acid extracted from $B$. subtilis spores by a respective method were determined by measuring solution absorbance at $260 \mathrm{~nm}(\mathrm{~A} 260)$ and at $280 \mathrm{~nm}$ (A280). Data are represented as mean \pm standard deviation $(\mathrm{SD})(\mathrm{n}=4)$.

抽出が可能であり, 分子生物学的な検査が可能であ ると考えられた。

\section{2. 微生物不活性化能の比較}

抽出操作の過程でぞれだけ芽胞が不活化（殺菌） されるか明らかにするため, $5 \times 10^{8} \mathrm{cfu}$ の枯草菌芽 胞を用いて, IT と BB 前処理試薬の核酸抽出工程 で生じる処理溶液中に残存する芽胞を検出した（操 作手順については Fig. 1 を参照). その結果, ITで は破砕液（破砕後のチューブに Buffer1 を混合した 状態）を原液のまま寒天培地に塗抹するとコロニー

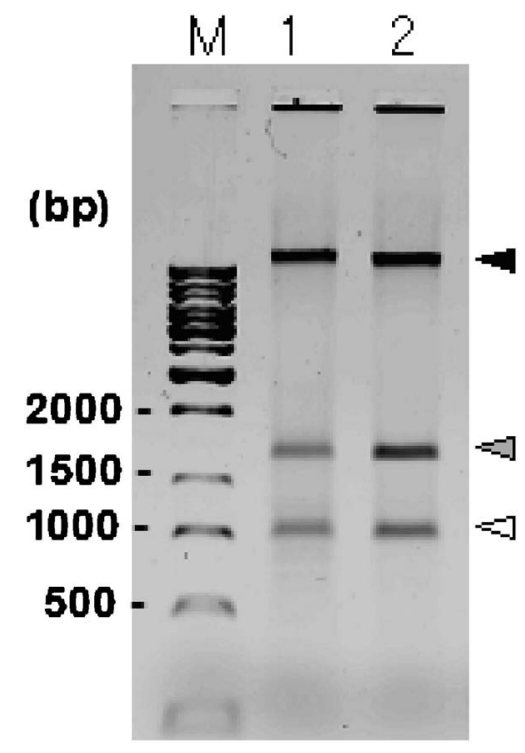

Fig. 3 Analysis of extracted DNA/RNA by agarose gel electrophoresis. B. subtilis spore extracts obtained in two independent expreriments using the BioBulwark ${ }^{\mathrm{TM}}$ reagent (Lane, 1 and 2) were electrophosed in $0.8 \%$ agarose with size standards of 500 bp Ladder marker (Lane, M). Black, gray and white arrow head indicates bacterial genomic DNA, $23 \mathrm{~S}$ ribosomal RNA (rRNA) and $16 \mathrm{~S}$ rRNA, respectively.

が生じてこないものの，破砕液を100倍または 10,000倍希釈して塗抹するとコロニーが生じ（デー タ未掲載), IT の破砕処理により残存する芽胞数は $1.8 \times 10^{3}$ 分の 1 に低下すると算出された。なお， DNA 精製用スピンカラムに通した後の抽出処理溶 液（カラム流出液, Buffer2 洗浄液, 最終溶出液) では，全てでコロニーの形成は認められなかった (データ未掲載)。一方，BBではビーズ破砕を行っ た直後の破砕処理液の原液抢よびその希釈液でもコ ロニー形成が認められなかった。 また，破砕工程以 降の処理液でもコロニー形成は認められなかった。 このことから，最初の処理工程である破砕処理で残 存する芽胞は $5 \times 10^{7}$ 分の 1 以下に低下すると算出 された（Fig. 4).なお，破砕処理前後に位相差顕 微鏡にて芽胞を観察したところ, 破砕前に認められ た芽胞が，破砕処理後にはBB とIT 共にほとんど 見られなかった（データ未掲載）. 
Table 1 Extraction of genomic DNA from the spore suspension of B. subtilis including contaminants ${ }^{\mathrm{a})}$.

\begin{tabular}{lcc}
\hline \multicolumn{1}{c}{ Contaminants } & $\begin{array}{c}\text { Amount of exracted DNA } \\
\left(\times 10^{7} \text { copies }\right)\end{array}$ & Efficiency $(\%)$ \\
\hline Silica & $6.3 \pm 0.5$ & 95 \\
\hline Sodium chloride & $5.0 \pm 0.3$ & 76 \\
\hline Ajinomoto (monosodium glutamate) & $4.0 \pm 0.2$ & 61 \\
\hline Cellulose & $3.9 \pm 0.3$ & 59 \\
\hline Coffee cream powder & $3.7 \pm 0.3$ & 56 \\
\hline PAL SWEET (aspertame) & $3.6 \pm 0.3$ & 55 \\
\hline Suger & $3.2 \pm 0.5$ & 49 \\
\hline Skim milk & $2.9 \pm 0.5$ & 45 \\
\hline Wheat flour & $2.5 \pm 0.3$ & 38 \\
\hline Starch & $2.0 \pm 0.1$ & 30 \\
\hline$-($ control) & $6.6 \pm 0.3$ & 100 \\
\hline
\end{tabular}

a) $1 \times 10^{8} \mathrm{cfu}$ of spore suspention including $5 \%(\mathrm{w} / \mathrm{v})$ of a respective white powder were prepared for the nucleic acid extraction with a BioBluwark reagent. Real-time PCR was performed to determine total copy number of $B$. subtilis genomic DNA in the extracted samples. Data are represented as mean $\pm \mathrm{SD}(\mathrm{n}=3)$.

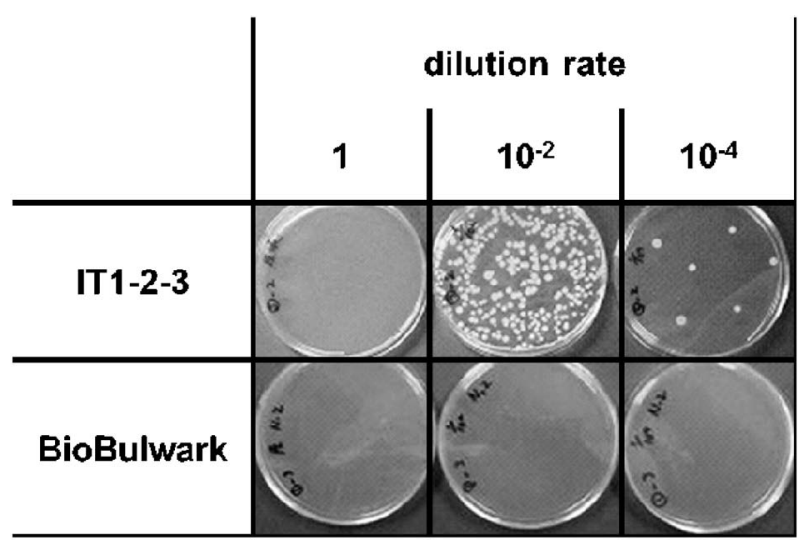

Fig. 4 Detection of viable cells in spore extracts. The supernatants after beads beating, which were shown in Fig. 1, were serially diluted in the indicated rate. Viable cells in each dilution were detected as colonies after overnight incubation on a LB agar plate.

\section{考 察}

本研究では, 分子生物学的な手法による生物剤検 知の前処理に用いられる核酸抽出キット IT, BB, 抢よび研究用核酸抽出試薬 MEの 3 種類について 核酸抽出特性を比較し，IT，BBについては抽出工 程による芽胞不活化能についても比較した。これら
のキットは細胞破砕にビーズを用いている点は共通 であるが，IT は精製にスピンカラムを用いてお り，他 2 法はアルコールを用いる点が異なってい る。また，ME は芽胞を含む幅広い微生物に使用さ れる核酸抽出試薬である。これを用いた細菌検出に 関する論文も多数報告されており, 研究分野では実 績のある核酸抽出試薬である6,7)。一方, IT と BB は生物剂からの核酸抽出を目的としたキットで, 屋 外での使用も考慮し, ME と比べると簡単な操作が 特徵となっている.

今回抽出対象に使用した枯草菌は, 炭疽菌と同じ Bacillus 属に分類され, その芽胞は類似の表層構造 をとることが知られている ${ }^{8)}$. 芽胞は強固な表層構 造により環境下での安定性が高く, 細菌がとる形態 のうち最も核酸抽出が困難である9 . IT および BB の核酸抽出量と精製度は ME と同等以上であっ た。 なた以前に我々は BB と類似の処理工程により グラム陽性菌, グラム陰性菌から IT, ME と同等 以上の核酸抽出量と精製度が得られることを報告し ている2).このことから，IT および BB も炭疽菌の ような芽胞を形成するグラム陽性菌からグラム陰性 菌までの幅広い細菌種に適応可能であると考えられ た.さらに，アガロースゲル電気泳動による解析か 
ら，RNA も分解など顕著な損傷を受けることなく 抽出可能であることが示唆され，出血熱ウイルスの 様な RNAウイルスに対しても有効な抽出法である と考えられた。

抽出効率および不活化能共に，BB を用いた場合 に最も良い成績を得た. その理由として, 他法と比 較し粒径が小さいビーズを使用しているため, 芽胞 との接触頻度が高く, 芽胞に効率よく物理的損傷を 与えることができること，高速振とうによって発生 するビーズの摩擦熱により溶液温度が高温となり, 熱変性により芽胞が不活化されることなどが考えら れた。な抢 BBでも，今回評価した量 $\left(5 \times 10^{8} \mathrm{cfu}\right)$ よりも多量の芽胞を扱った場合は, 破砕後の処理液 に芽胞が残存する可能性があるので, 注意が必要で ある. IT では破砕液（破砕後のチューブに Buffer1 を混合した状態）を原液のます培地に塗抹するとコ ロニーが生じてこないものの, 破砕液を希釈して培 地に塗抹するとコロニーが生じた（Fig. 4).この 現象は, IT の破砕液に含まれる成分（グアニジン 塩酸塩など）が芽胞から栄養型への発芽および栄養 型の増殖を妨げていることが原因であると推察さ れ, ビーズ破砕後の溶液中にも活性のある芽胞が残 存することを示している. 破砕液をDNA 精製用ス ピンカラムに通した後の最終溶出液ではコロニー形 成は認められなかったことから（データ未掲載）, 破砕処理で残存する芽胞がスピンカラムにトラップ されると考えられた. IT では処理工程で生じる廃 液, カラムなどに生菌（芽胞）が残存する可能性が 高いと思われる。

不純物の影響評価について，今回は BBのみでの 評価となったが，検討した不純物全てに対し，分子 生物学的検查に使用可能な核酸を抽出できることが 分かった. 本研究と同様, 複数の市販抽出キットに ついて芽胞が混入する粉末試料からの DNA 抽出効 率を比較した結果が報告されている10)。この報告で は，1 マイクロリットル白金耳で採取された量の粉 末を抽出操作に用いている. この粉末量は, 一般的 に想定される抽出操作への持ち込久量に相当する.

一方, 本研究では不純物の影響をより顕著にするた め, 過剩量の粉末試料を抽出試薬に持ち込反検討を 行った。今回不純物を終濃度 5\%（w/v）になるよ
う添加したが，小麦粉や片栗粉などの難溶性の粉末 を用いた場合，抽出試薬は強い白濁を示した．BB による抽出工程では，水溶性粉末が不純物として混 入する場合，核酸洗浄・精製時に溶液から除去可能 である。一方，過剰の難溶性粉末が芽胞と共存する 場合，核酸精製時に多くは除去可能であるが，核酸 洗浄・精製後もわずかに最終溶解液中に残り，核酸 を吸着し溶解性を低下させるなどの影響を与えてい る可能性が考えられた．実際の検査でも難溶性の不 純物が過剰に共存する場合は, 抽出効率の低下ある いは遺伝子検出感度の低下などの影響が出ることが 考えられる。したがって，スワブにより被疑試料を 採取し BB またはITにて抽出する場合, 試薬へ多 量の被疑試料を持ち込まない，あるいは数倍希釈し た後に用いるなど工夫が必要と思われる.

今回評価したキットは，何れも生物剂検知を目的 とした核酸抽出に使用可能であると思われるが，抽 出効率や微生物の不活化能などには差があることか ら，キットの特性を理解して使用することが重要で ある。

\section{謝 辞}

本研究の一部は, 科学技術振興事業団 (JST) の 戦略的創造研究推進事業 (CREST) 研究領域「先 進的統合センシング技術」. 研究課題.「全自動モバ イル型生物剂センシングシステム。 (平成17年10月 〜平成 20 年 9 月)」の支援によるものである.

\section{文 献}

1）瀬戸康雄: 生物化学剤の現場検知法. 分析化 学, 55, 891-906 (2006).

2）黑崎陽平, 堀内秀紀, 藤浪良仁, 橋本幸二, 安田二朗 : 微生物核酸の迅速簡易抽出法の開発 とその応用. 日本法科学技術学会誌，15, 135142 (2010).

3) Wills, B., Leikin, J. B., Rhee, J., Tameling, C. and Saeedi, B.: Analysis of suspicious powders following the post 9/11 anthrax scare. J. Med. Toxicol., 4, 93-95 (2008).

4) Moszer, I.: The complete genome of Bacillus subtilis: from sequence annotation to data 
management and analysis. FEBS Letters, 430, 2836 (1998).

5) Griffiths, R., Whiteley, A., O'donnell, A., and Bailey, M.: Rapid method for coextraction of DNA and RNA from natural environments for analysis of ribosomal DNA- and rRNA-based mircobial community composition. Appl. Environ. Microbiol., 66, 5488-5491 (2000).

6) Fukasawa, C., Ohkusu, K., Sanayama, Y., Yasufuku, K., Ishiwada, N. Ezaki, T., and Kohno, Y.: A mixed bacterial infection of a bronchogenic lung cyst diagnosed by PCR. J. Med. Microbiol., 55, 791-4 (2006).

7) Ohtsuki, R., Kawamoto, K., Kato, Y., Shah, M. M., Ezaki, T. and Makino, S-I.: Rapid detection of Brucella spp. by the loop-mediated isothermal amplification method. J. Appl.
Microbiol., 104, 1815-1823 (2008).

8) Henriques A. O. and Moran C. P. Jr.: Structure, assembly, and function of the spore surface layers. Annu. Rev. Microbiol., 61, 555-88 (2007).

9) Dauphin, L. A., Moser, B. D. and Bowen, M. D.: Evaluation of five commercial nucleic acid extraction kits for their ability to inactivate Bacillus anthracis spores and comparison of DNA yields from spores and spiked environmental samples. $J$. Microbiol. Methods, 76, 30-7 (2009).

10) Rose, H., Dewey, C., Ely, M., Willoughby, S., Parsons, T., Cox, V., Spencer, P., and Weller, S.: Comparison of eight methods for the extraction of Bacillus strophaeus spore DNA from eleven common interferents and a common swab. PLoS One, 6, e22668 (2011). 